\title{
PENERAPAN MODEL ARGUMENT-DRIVEN INQUIRY (ADI)DALAM MENINGKATKAN KEMAMPUAN BERARGUMENTASI SISWA PADA KONSEP PENCEMARAN LINGKUNGAN DI KELAS X SMA NEGERI 1 CIAWIGEBANG
}

\author{
Ofi Shofiyatun Marhamah ${ }^{1)}$, Ilah Nurlaelah ${ }^{2)}$, Ina Setiawati ${ }^{3)}$ \\ ${ }^{1}$ Program Studi Pendidikan Biologi FKIP, Universitas Kuningan \\ ${ }^{2}$ Program Studi Pendidikan Biologi FKIP, Universitas Kuningan \\ Email: ilah.nurlaelah@uniku.ac.id \\ ${ }^{3}$ Program Studi Pendidikan Biologi FKIP, Universitas Kuningan \\ Email: ina.setiawati@uniku.ac.id
}

APA Citation: Marhamah, O.S., Nurlaelah, I., \& Setiawati, I. (2017). Penerapan Model Argument-Driven Inquiry (ADI)Dalam Meningkatkan Kemampuan Berargumentasi Siswa Pada Konsep Pencemaran Lingkungan Di Kelas X Sma Negeri 1 Ciawigebang. Quagga: Jurnal Pendidikan dan Biologi, 9(2), 39-45. doi: 10.25134/quagga.v9i02.747.

\begin{abstract}
Abstrak: Latar belakang dari penelitian ini adalah kurang terlatihnya kemampuan argumentasi siswa, hal ini dikarenakan kurangnya pengetahuan guru tentang model-model pembelajaran yang dapat melatih kemampuan berargumentasi. Pemilihan model pembelajaran yang tepat akan berpengaruh terhadap kualitas pembelajaran yang berimplikasi pada kemampuan berargumentasi siswa. Salah satu model yang menjadi alternatif untuk meningkatkan kemampuan berargumentasi adalah model pembelajaran Argument-Driven Inquiry(ADI). Keterampilan berargumentasi berperan penting dalam membangun suatu eksplanasi, model dan teori dari suatu konsep yang dipelajari, dengan melatih keterampilan berargumentasi berarti melatih kemampuan kognitif dan afektif yang dapat digunakan untuk membantu memahami konsep-konsep dalam biologi. Penelitian ini bertujuan untuk meningkatkan kemampuan berargumentasi siswa di SMA. Penelitian ini merupakan penelitian eksperimental. Penelitian ini dirancang dengan menggunakan desain Pretest-Posttest Control Group Design. Populasi penelitian ini adalah semua siswa kelas XI IPA di SMA Negeri 1 Ciawigebang tahun pelajaran 2015/2016 sebanyak 9 kelas. Pengambilan sampel dengan menggunakan teknik cluster random sampling. Sampel penelitian yaitu kelas X 4 sebagai kelas eksperimen dan X 1 sebagai kelas kontrol. Pengumpulan data dengan tes uraian, metode observasi (asesmen kinerja argumentasi dan lembar observasi ADI) angket dan dokumentasi. Uji hipotesis dengan menggunakan uji statistik parametrik dalam hal ini untuk uji hipotesis peningkatan menggunakan uji $t$ didapatkan $p<0,05$ yaitu 0,000 $<0,05$ yang artinya penerapan model pembelajaran Argument-Driven Inquiry (ADI)dapat meningkatkan kemampuan berargumentasi siswa pada konsep Pencemaran Lingungan di kelas X SMA Negeri 1 Ciawigebang.
\end{abstract}

Kata kunci : Model Argument-Driven Inquiry (ADI), Kemampuan Berargumentasi

\begin{abstract}
The background of this study is the lack of training in students' argumentation skills, this is due to the lack of teacher knowledge about learning models that can practice argumentation skills. The selection of the right learning model will affect the quality of learning which has implications for students' ability to argue. One model that is an alternative to improving the ability to argue is a learning model of Argument-Driven Inquiry (ADI). Argumentation skills play an important role in building an explanation, the model and theory of a concept that is learned, by practicing argumentation skills means training cognitive and affective abilities that can be used to help understand concepts in biology. This study aims to improve the ability to argue students in high school. This research is an experimental study. This study was designed using the Pretest-Posttest Control Group Design design. The population of this study was all students of class XI IPA in Ciawigebang 1 Public High School in the 2015/2016 school year as many as 9 classes. Sampling using cluster random sampling technique. The research sample is class $X 4$ as the experimental class and X 1 as the control class. Data collection with description test, observation method (argumentation performance assessment and ADI observation sheet) questionnaire and documentation. Hypothesis testing using parametric statistical tests in this case to test the increasing hypothesis using the t test obtained $p<0.05$, which is $0,000<0.05$, which means that the implementation of the Argument-Driven Inquiry (ADI) learning model can improve students' ability to argue with the concept of Insoluble Pollution in class X of Ciawigebang 1 Public High School.
\end{abstract}

Keywords: Model Argument-Driven Inquiry (ADI), Ability to Argue 
Quagga: Jurnal Pendidikan dan Biologi

Volume 9, Nomor 2, Juli 2017

\section{PENDAHULUAN}

Pendidikan Ilmu Pengetahuan Alam (IPA) diharapkan dapat menjadi wahana bagi peserta didik untuk mempelajari diri sendiri dan alam sekitar, serta prospek pengembangan lebih lanjut dalam menerapkannya di dalam kehidupan sehari-hari. Pembelajaran IPA diharapkan dapat menumbuhkan kemampuan berpikir, bekerja dan bersikap ilmiah serta mengkomunikasikannya sebagai aspek penting kecakapan hidup (Andriani et al., 2015). Salah satu kemampuan yang penting untuk dilatihkan kepada siswa didalam kegiatan pembelajaran IPA adalah argumentasi ilmiah, dengan berargumentasi ilmiah siswa mampu mengemukakan ide atau gagasan yang mampu menunjukkan hubungan antara hasil pemikiran dengan bukti nyata yang ada dalam sains (Duschl et al., dalam Sukma 2014).

Osborne (dalam Budiyono et al., 2015)mendefinisikan argumentasi sebagai upaya untuk memvalidasi atau menyangkal klaim atas dasar alasan dengan cara yang mencerminkan nilai-nilai ilmiah. Sebuah klaim, dalam konteks ini, bukan hanya pendapat atau ide. Klaim adalah dugaan, penjelasan, atau kesimpulan yang memberikan jawaban pertanyaan penelitian. Sedangkan Keraf (2010:3) mengemukakan bahwa argumentasi adalah suatu bentuk retorika yang berusaha untuk mempengaruhi sikap dan pendapat orang lain, agar mereka itu percaya dan akhirnya bertindak sesuai dengan apa yang diinginkan oleh penulis atau pembicara. Dalam mengemukakan argumentasi, seseorang harus mengumpulkan fakta-fakta sedemikian rupa sehingga ia mampu menunjukkan suatu pendapat atau suatu hal itu benar atau tidak melalui argumentasi. Jadi dasar pendapat yang bersifat argumentatif adalah berpikir dan logis.

Kemampuan berargumentasi ini dapat membekali siswa dimasa yang akan datang dilingkungan sosial, selain itu gagasan pentingnya keterampilan berargumentasi menurut Zohar dan Nemet (dalam Siswanto et al., 2014) bahwa keterampilan berargumentasi berperan penting dalam membangun suatu eksplanasi, model dan teori dari suatu konsep yang dipelajari, dengan melatih keterampilan berargumentasi berarti melatih kemampuan kognitif dan afektif yang dapat digunakan untuk membantu memahami konsep-konsep dalam biologi.

Selain itu, menurut Erduran (dalam Roshayanti, 2012) argumentasi memiliki kontribusi dalam pembelajaran sains di kelas dapat dikelompokkan dalam lima dimensi.
p-ISSN 1907-3089, e-ISSN 2651-5869

https://journal.uniku.ac.id/index.php/quagga

Dimensi pertama, argumentasi mendukung keberadaan proses kognitif dan metakognitif sesuai karakteristik kinerja para ahli yang dapat menjadi model bagi siswa. Dimensi kedua, mendukung perkembangan kompetensi komunikasi dan berpikir kritis. Dimensi ketiga mendukung pencapaian literasi sains serta melatih siswa untuk berbicara dan menulis dengan menggunakan bahasa sains. Dimensi keempat mendukung enkulturasi kedalam praktek budaya ilmiah serta mengembangkan kriteria epistemik untuk mengevaluasi pengetahuan. Dimensi kelima mendukung pengembangan penalaran, khususnya dalam pemilihan teori atau penentuan sikap berdasarkan kriteria rasional.

Berdasarkan hasil penelitian Sondang dan Muslim (dalam Siswanto et al., 2014), dan Puji (2014) mengemukakan bahwa sebagian besar siswa belum terampil dalam menulis argumentasi sains, rata-rata sebagian siswa memiliki kemampuan argumentasi hanya mencapai level 2, dimana siswa berargumen dari suatu claim melawan claim lain dengan data pendukung namun tidak berisi sanggahan. Belum terlatihnya kemampuan berargumentasi siswa disebabkan kurangnya pengetahuan guru tentang modelmodel pembelajaran yang dapat melatih kemampuan berargumentasi. Pemilihan model pembelajaran yang tepat akan berpengaruh terhadap kualitas pembelajaran yang berimplikasi pada kemampuan berargumentasi siswa. Salah satu model yang menjadi alternatif untuk meningkatkan kemampuan berargumentasi adalah model pembelajaran Argument-Driven Inquiry(ADI).

Model pembelajaran Argument-Driven Inquiry (ADI) merupakan salah satu model pembelajaran yang didesain untuk menyiapkan dan memberikan kesempatan kepada siswa untuk mengembangkan metode mereka sendiri dalam memperoleh data, melakukan investigasi, menggunakan data untuk menjawab pertanyaan penyelidikan, menulis dan berpikir lebih reflektif. Model ADI ini memberikan kesempatan bagi siswa untuk terlibat dalam argumentasi ilmiah dan peer-review (Walker dalam Mutia, 2015).

ADI merupakan pembelajaran berbasis Inquiryyang dikembangkan untuk memberikan kesempatan kepada siswa untuk mempelajari IPA (learning science) dengan doing science. Model pembelajaran $A D I$ terdiri atas delapan langkah pembelajaran, yaitu mengidentifikasi tugas (task), dan pertanyaan penyelidikan, mengumpulkan data, membuat suatu argumen tentatif, sesi argumentasi, diskusi reflektif dan 
Quagga: Jurnal Pendidikan dan Biologi

Volume 9, Nomor 2, Juli 2017

eksplisit, membuat laporan investigasi tertulis, melakukan peer review tersamar ganda, dan melakukan revisi lanjutan terhadap laporan siswa (Mutia, 2015). Pembelajaran dengan menekankan kegiatan argumentasi berpotensi dapat membuat siswa lebih aktif karena melalui kegiatan ini siswa menghubungkan ide-ide dan bukti yang dapat dia gunakan untuk memvalidasi ide yang mereka kemukakan serta mengkomunikasikannya. Pembelajaran Argument- Driven Inquiry (ADI) dipandang dapat memfasilitasi untuk mengajarkan kemampuan argumentasi tersebut (Andriani et al., 2015).

Salah satu materi yang dipelajari di SMA Negeri 1 Ciawigebang Kelas X adalah konsep Pencemaran Lingkungan. Konsep tersebut sangat relevan untuk melatih argumentasi karena membahas gangguan-gangguan lingkungan yang terjadi dalam kehidupan sehari-hari. Adanya permasalahan mendorong siswa untuk terlatih dalam memecahkan masalah sehingga meningkatkan kemampuan argumentasi mereka. Dalam memecahkan masalah siswa dituntut untuk mengemukakan faktor penyebab masalah berdasarkan data dan fakta, dampak yang ditimbulkan berdasarkan teori yang mendukung, dan solusi dalam mengatasi masalah tersebut, sehingga dapat mengembangkan kemampuan argumentasi siswa.

\section{METODOLOGI PENELITIAN Metode Penelitian}

Metode penelitian ini menggunakan metode eksperimental. Adapun bentuk desain yang digunakan dalam penelitian ini adalah PretestPosttest Control Group Design. Variabel bebas pada penelitian ini adalah model ArgumentDriven Inquiry $(A D I)$, dan variabel terikat yaitu kemampuan berargumentasi.

Tabel 1. Desain Pretest-Posttest Control Group

\begin{tabular}{ll}
\multicolumn{2}{c}{ Design } \\
\hline $\mathrm{R}$ & $\mathrm{O}_{1}($ PretestADI $) \mathrm{XO}_{2}($ Posttest ADI $)$ \\
$\mathrm{R}$ & $\mathrm{O}_{3}$ (Pretest Inquiry) $\mathrm{O}_{4}($ Posttest Inquiry) \\
\hline
\end{tabular}

\section{Populasi dan Teknik Pengambilan Sampel Populasi}

Populasi dalam penelitian ini adalah seluruh siswa kelas X SMA Negeri 1 Ciawigebang.

Sampel

Pengambilan sampel dilakukan dengan cara cluster random sampling. Dari 9 kelas X diambil 2 kelas yaitu 1 kelas sebagai kelas eksperimen $(A D I)$ dan 1 kelas sebagai kelas kontrol (Inquiry).
p-ISSN 1907-3089, e-ISSN 2651-5869

https://journal.uniku.ac.id/index.php/quagga

\section{Teknik Pengumpulan Data}

Penelitian ini menggunakan tiga metode pengumpulan data. Teknik tes digunakan untuk mengambil data kemampuan berargumentasi dalam bentuk tes essay. Metode observasi terdiri dari asesmen kinerja argumentasi yang digunakan untuk mengambil data kemampuan berargumentasi lisan saat proses pembelajaran dan Lembar Observasi model ADI untuk mengetahui keterlaksanaan model $A D I$. Instrumen penelitian berupa tes yang telah diuji cobakan untuk diketahui validitas dan reliabilitasnya.

\section{Teknik analisis data}

Uji Prasyarat Analisis

Untuk dapat menggunakan uji hipotesis, harus dilakukan uji prasyarat analisis meliputi uji normalitas dan homogenitas.

\section{Pengujian Hipotesis}

Pengujian hipotesis dengan uji $\mathrm{t}$ nilai posttest, pada taraf signifikan $\alpha=0,05$ menggunakan bantuan software SPSS.

Peningkatan pada kemampuan argumentasi digunakan perhitungan gain.

$$
\begin{aligned}
& n \text {-gain }=\frac{(\text { skorposttest-skorpretest })}{(\text { skormaksimal-skorpretest })} \\
& \text { (Meltzer dalam Susanti, 2013) }
\end{aligned}
$$

Hasil perhitungan gain diinterpretasikan menggunakan indeks gain menurut klasifikasi Meltzer (2002).

\section{HASIL DAN PEMBAHASAN \\ Data Hasil Tes Uraian \\ Data Hasil Pretest}

Tabel 2. Nilai Rata-rata Pretest

\begin{tabular}{ccc}
\hline Kelas & $\begin{array}{c}\text { Jumlah } \\
\text { Siswa }\end{array}$ & $\begin{array}{c}\text { Nilai Rata-rata } \\
\text { Pretest }\end{array}$ \\
\hline Eksperimen & 38 & 34,84 \\
\hline Kontrol & 38 & 33,84 \\
\hline
\end{tabular}

Berdasarkan hasil uji t $\mathrm{p}>0,05$ yaitu 0,494 > 0,05 , artinya tidak terdapat perbedaan pada kemampuan awal siswa, jadi dapat disimpulkan bahwa kemampuan awal siswa pada kelas eksperimen dan kontrol itu sama. Pada kelas eksperimen nilai rata-rata pretest yaitu 34,84 dan pada kelas kontrol yaitu 33,84. 
Quagga: Jurnal Pendidikan dan Biologi

Volume 9, Nomor 2, Juli 2017

Data Hasil Posttest

Tabel 3. Nilai Rata-rata Posttest

\begin{tabular}{ccc}
\hline Kelas & $\begin{array}{c}\text { Jumlah } \\
\text { Siswa }\end{array}$ & $\begin{array}{c}\text { Nilai Rata-rata } \\
\text { Posttest }\end{array}$ \\
\hline Eksperimen & 38 & 63,07 \\
\hline Kontrol & 38 & 51,67 \\
\hline
\end{tabular}

Berdasarkan hasil uji t $\mathrm{p}<0,05$ yaitu $0,00<$ 0,05 yang artinya penerapan model pembelajaran Argument-Driven Inquiry (ADI) berpengaruh terhadap kemampuan argumentasi siswa.

Adanya pengaruh penerapan model Argument-Driven Inquiry (ADI) terhadap kemampuan argumentasi siswa tersebut karena model Argument-Driven Inquiry (ADI) memfasilitasi siswa untuk berargumentasi melalui fase argumen tentatif dan sesi argumentasi, sehingga siswa mampu mengembangkan kebiasaan berpikir ilmiah.

Hasil penelitian tersebut sesuai dengan kemanfaatan model Argument Driven Inquiry(ADI) menurut Sampson et al., (2009) yang menyatakan bahwa model Argument Driven Inquiry(ADI) membantu pengembangan literasi sains dan membantu siswa dalam mengembangkan kebiasaan berpikir ilmiah. Analisis n-gain

Tabel 4. Hasil Rata-rata Indeks $N$-gain

\begin{tabular}{lccl}
\hline \multicolumn{1}{c}{ Kelas } & $\begin{array}{c}\text { Jumlah } \\
\text { Siswa }\end{array}$ & $\begin{array}{c}\text { Indeks } \\
\text { Gain }\end{array}$ & Kriteria \\
\hline Eksperimen & 38 & 0,43 & Sedang \\
\hline Kontrol & 38 & 0,26 & Rendah \\
\hline
\end{tabular}

Bedasarkan hasil uji n-gain dapat diketahui bahwa penerapan model Argument-Drivent Inquiry (ADI) dapat meningkatkan kemampuan berargumentasi siswa.

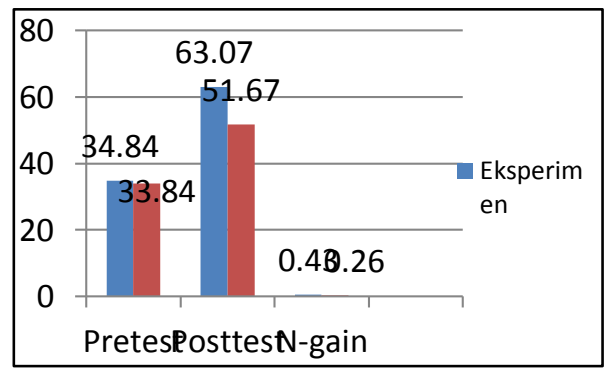

Gambar 1. Nilai rata - rata pretest, posttest dan $n$-gain kelas eksperimen dan kelas kontrol

Berdasarkan gambar diatas dapat diketahui bahwa kelas eksperimen memiliki rata-rata indeks $n$-gain lebih tinggi dibandingkan kelas kontrol. Indeks n-gain kelas eksperimen yaitu
p-ISSN 1907-3089, e-ISSN 2651-5869

https://journal.uniku.ac.id/index.php/quagga

0,43 termasuk kriteria peningkatan sedang dan indeks $n$-gain kelas kontrol yaitu 0,26 termasuk kriteria peningkatan rendah.

Peningkatan kemampuan argumentasi kelas eksperimen yang menerapkan model ArgumentDriven Inquiry ( $A D I$ ) lebih tinggi dari pada kelas kontrol yang tidak menerapkan model ArgumentDriven Inquiry (ADI). Mutia (2015) menjelaskan bahwa pembelajaran dengan Argument-Driven Inquiry ( $A D I)$ dapat meningkatkan kemampuan berargumentasi ilmiah dan rasa ingin tahu siswa SMP, karena model Argument-Driven Inquiry (ADI) merupakan model pembelajaran yang berpotensi membantu siswa membangun argumentasi ilmiah yang berkualitas melalui sesi argumentasi dan membuat laporan hasil penyelidikan yang mengembangkan kemampuan siswa dalam membuat kesimpulan yang valid berdasarkan bukti-bukti hasil penyelidikan.

Menurut Anderson \&Cobern et al (dalam Demircioglu, T. et al., 2015) Penyelidikan ilmiah adalah dasar untuk penelitian dan studi. Evaluasi dan interpretasi bukti, evaluasi validitas pengetahuan ilmiah, dan berpikir tentang ide-ide yang berbeda dalam proses penyelidikan ilmiah adalah elemen inti dari argumentasi dan ilmu pengetahuan. Adapun persentase kemampuan argumentasi tiap level pada kelas eksperimen dapat dilihat pada gambar berikut ini :

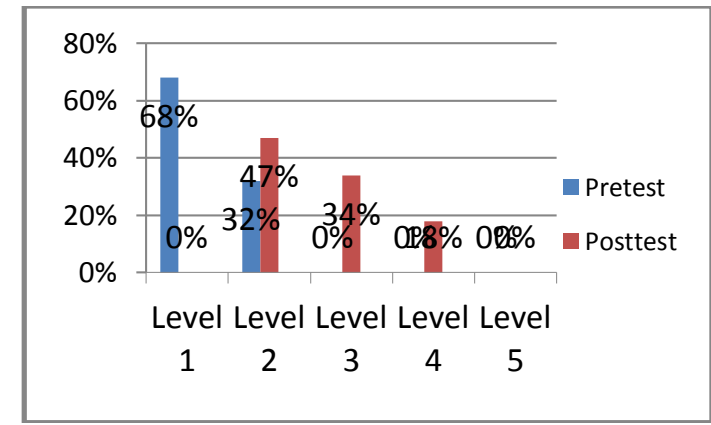

Gambar 2. Persentase Kemampuan Argumentasi tiap Level pada Kelas Eksperimen

Dari gambar tersebut, jelas telihat adanya peningkatan kemampuan argumentasi tiap level. Sebelum penerapan model ADI kemampuan argumentasi siswa hanya mencapai level 2 dan setelah penerapan model ADIkemampuan argumentasi siswa mencapai level 4.

Sedangkan persentase kemampuan argumentasi tiap level pada kelas kontrol dapat dilihat pada gambar berikut ini : 
Quagga: Jurnal Pendidikan dan Biologi

Volume 9, Nomor 2, Juli 2017

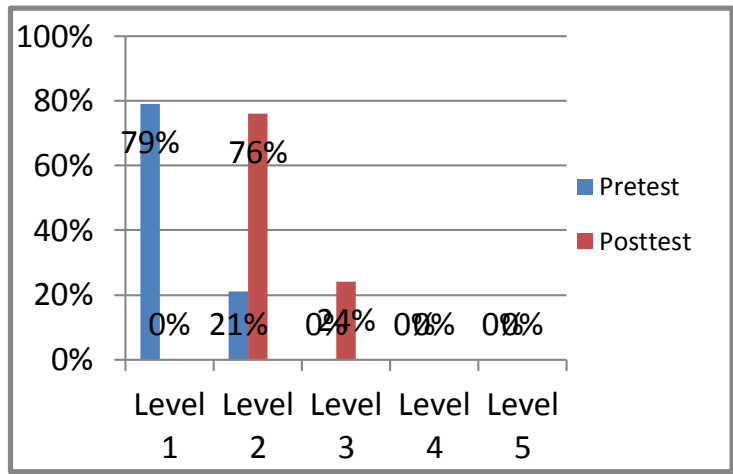

Gambar 3. Persentase Kemampuan Argumentasi tiap Level pada Kelas Kontrol

Dari gambar tersebut, jelas telihat adanya peningkatan kemampuan argumentasi tiap level. Sebelum penerapan model Inquiry kemampuan argumentasi siswa hanya mencapai level 2 dan setelah penerapan model Inquiry kemampuan argumentasi siswa mencapai level 3.

Model Argument-Driven Inquiry (ADI) dapat meningkatkan penguasaan konsep siswa, hal tersebut sesuai dengan hasil penelitian Andriani (2015) yang menyatakan model pembelajaran Argument-Driven Inquiry (ADI) dipandang dapat memfasilitasi siswa untuk memahami konsep IPA secara baik, karena kegiatan pembelajaran pada model ArgumentDriven Inquiry (ADI) menekankan pada kontruksi dan validasi pengetahuan melalui kegiatan penyelidikan. Model ini dirancang untuk membuat sebuah kelas yang dapat membantu siswa untuk mengerti tentang bagaimana cara membuat sebuah penjelasan ilmiah, bagaimana mengeneralisasikan fakta ilmiah, menggunakan data untuk menjawab pertanyaan ilmiah dan pada akhirnya dapat merefleksikan hasil kerja yang telah dilakukannya. Dengan terlibat pada sesi argumentasi dalam model Argument Driven Inquiry $(A D I)$ siswa dapat menguasai konsep lebih baik, karena untuk membangun argumen yang baik siswa membutuhkan penguasaan pengetahuan tentang konten materi yang baik pula.

Hal tersebut didukung oleh Eemeren \& Grootendorst (dalam Karisan, D. et al., 2016) yang mendefinisikan argumentasi sebagai kegiatan verbal, sosial, dan rasional yang bertujuan untuk meyakinkan seseorang. Berdasarkan definisi tersebut, argumentasi tidak hanya karakteristik lisan tetapi juga sosial dan rasional. Proses verbal dan sosial argumentasi meningkatkan keterampilan komunikasi siswa,
p-ISSN 1907-3089, e-ISSN 2651-5869

https://journal.uniku.ac.id/index.php/quagga

proses rasional argumentasi meningkatkan proses keterampilan kognitif.

Adanya peningkatan kemampuan berargumentasi siswa ini didukung oleh hasil asesmen kinerja argumentasi kelompok sebagai berikut :

Tabel 5. Argumentasi Lisan Kelompok Eksperimen

\begin{tabular}{|c|c|c|c|c|c|c|c|}
\hline \multirow{2}{*}{$\begin{array}{c}\text { Kel } \\
\text { Eksp }\end{array}$} & \multicolumn{5}{|c|}{ Indikator } & \multirow{2}{*}{ Level } & \multirow{2}{*}{ Nilai } \\
\hline & $\mathbf{C}$ & $\mathbf{D}$ & W & $\mathbf{B}$ & $\mathbf{R}$ & & \\
\hline 1 & 1 & 1 & 2 & 1 & 1 & 4 & 80 \\
\hline 2 & 1 & 1 & 1 & & & 2 & 40 \\
\hline 3 & 1 & 1 & 1 & 1 & 1 & 3 & 60 \\
\hline 4 & 1 & 2 & 2 & 1 & 1 & 4 & 80 \\
\hline 5 & 1 & 1 & 1 & & & 2 & 40 \\
\hline 6 & 1 & 1 & 1 & 1 & 1 & 3 & 60 \\
\hline Rat & at: & ev & K & $n p$ & & 3 & \\
\hline
\end{tabular}

Berdasarkan tabel 5 dapat diketahui bahwa kemampuan argumentasi lisan siswa tiap kelompok pada kelas eksperimen berbeda-beda. Kelompok 1 dan kelompok 4 berada pada level 4 dengan nilai yang diperoleh yaitu 80. Kelompok 3 dan 6 dengan nilai yang diperoleh yaitu 60 berada pada level 3. Sedangkan kelompok 2 dan kelompok 5 dengan nilai yang diperoleh yaitu 40 , berada pada level 2 .

Rata-rata kemampuan argumentasi lisan kelompok kelas eksperimen mencapai level 3, dimana siswa dapat mengemukakan argumen berisi suatu rangkaian claim atau claim berlawanan dengan data pendukung dan sedikit sanggahan.

Adanya peningkatan level argumentasi setelah penerapan model Argument-Driven Inquiry (ADI) juga sesuai dengan hasil penilaian melalui lembar asesmen kinerja argumentasi, pada saat proses sesi argumentasi yang mana kemampuan argumentasi siswa meningkat karena siswa menemukan sendiri bukti dari hasil penyelidikan. Hal tersebut didukung oleh Sampson et al., (2009) yang menyatakan bahwa pada sesi argumentasi ini didesain agar siswa meninjau secara kritis suatu produk (klaim atau argumen), proses (metode), dan konteks (landasan teori) dari suatu inquiry, sehingga pada sesi ini diharapkan dapat membantu siswa dalam mempelajari bagaimana aspek sosial dalam argumentasi ilmiah dengan bukti, teori atau hukum ilmiah.

Hasil peer review double-blind laporan penyelidikan berikut ini mendukung adanya peningkatan kemampuan argumentasi. 
Quagga: Jurnal Pendidikan dan Biologi

Volume 9, Nomor 2, Juli 2017

Tabel 6. Rekapitulasi Persentase Tiap Kriteria Hasil Double-BlindPeer Review Laporan Penyelidikan

\begin{tabular}{ccccc}
\hline Kriteria & Hasil & Penyelidikan & Argumen & $\begin{array}{c}\text { Penulis } \\
\text { an }\end{array}$ \\
\hline $\begin{array}{c}\text { Persentase } \\
\text { tiap kiteria } \\
(\%)\end{array}$ & 93 & 86 & 81 & 88 \\
\hline
\end{tabular}

Hampir semua siswa dapat membuat laporan hasil penyelidikan dengan baik, hanya beberapa orang yang masih perlu perbaikan. Melalui fase ini siswa didorong untuk mengembangkan dan menggunakan standar yang tepat dalam menilai suatu argumen yang berkualitas, mengembangkan metakognisi siswa, dan menciptakan komunitas pembelajar yang menghargai pentingnya suatu bukti dan berpikir kritis didalam kelas (Sampson et al., 2009), jadi pada fase ini kemampuan argumentasi siswa dapat meningkat karena siswa tidak hanya mampu berargumen ilmiah namun siswa juga dapat menganalisis argumen siswa lainnya.

Selain itu peningkatan kemampuan argumentasi didukung dengan hasil analisis lembar observasi keterlaksanaan model Argument-Driven Inquiry (ADI), dimana keterlaksanaan model tersebut yaitu sekitar 95\% yang artinya hampir seluruh kegiatan terlaksana, adapun $5 \%$ proses model Argument-Driven Inquiry (ADI) yang tidak terlaksana yaitu pada fase terakhir yaitu merevisi lebih lanjut laporan hasil penyelidikan, dimana guru tidak meminta siswa mengumpulkan hasil revisian penyelidikan, guru hanya mengarahkan cara merevisi lebih lanjut laporan penyelidikan tersebut dikarenakan waktu yang diberikan tidak cukup. Jika penerapan model Argument-Driven Inquiry (ADI) ini terlaksana $100 \%$, kemungkinan besar akan lebih meningkatkan lagi kemampuan argumentasi siswa.

\section{SIMPULAN}

Berdasarkan hasil analisis data dan pembahasannya dapat diambil kesimpulan. Berdasarkan hasil uji hipotesis diperolehp $<0,05$ yaitu $0,00<0,05$ artinya penerapan model Argument-Driven Inquiry (ADI) berpengaruh terhadap kemampuan berargumentasi siswa. Hal ini didukung dengan hasil indeks n-gain yang didapat pada kelas eksperimen yaitu 0,43 termasuk kriteria peningkatan sedang. Berdasarkan hasil analisis data tersebut dapat disimpulkan bahwa model Argument-Driven Inquiry ( $A D I)$ dapat meningkatkan kemampuan
p-ISSN 1907-3089, e-ISSN 2651-5869

https://journal.uniku.ac.id/index.php/quagga

berargumentasi siswa. Level kemampuan berargumentasi siswa sebelum diberi perlakuan model Argument-Driven Inquiry (ADI) beradapada level 1 , sedangkan setelah diberi perlakuan model Argument-Driven Inquiry (ADI) level kemampuan berargumentasi siswa dapat mencapai level 3. Hal tersebut karena model Argument-Driven Inquiry (ADI) dapat memfasilitasi siswa untuk melatih kemampuan berargumentasi dan kualitas argumentasi siswa, salah satunya pada tahapan pembuatan argumen tentatif serta tahap sesi argumentasi.

\section{REFERENSI}

Andriani, Y. dan Riandi. 2015. Perbandingan Aktifitas Siswa dan Guru dalam Pembelajaran Argument Driven Inquiry dan Inkuiri Terbimbing pada Pembelajaran IPA Terpadu Kelas VII.Prosiding Simposium Nasional Inovasi dan Pembelajaran Sains 2015 (SNIPS 2015) 8 dan 9 Juni 2015, Bandung, Indonesia. (Online). Tersedia : http://portal.fi.itb.ac.id/snips2015/files/sn ips 2015 yuli andriani $73 \mathrm{c} 72 \mathrm{f} 488 \mathrm{e} 2992$ f4d2c0053237fa705e.pdf. Diakses 15 Februari 2016.

Andriani, Y. dan Riandi. 2015. Peningkatan Penguasaan Konsep Siswa Melalui Pembelajaran Argument Driven Inquiry pada Pembelajaran IPA Terpadu Di SMP Kelas VII. Research Artikel EDUSAINS, 7 (2), 2015, 114-120. (Online). Tersedia : http://journal.uinjkt.ac.id/index.php/edus ains. Diakses 20 Mei 2016.

Budiyono, A., Rusdiana, D., Ida. S.K. 2015. Pembelajaran Argument Based Science Inquiry (ABSI) Pada Fisika. Prosiding Simposium Nasional Inovasi dan Pembelajaran Sains 2015 (SNIPS 2015) 8 dan 9 Juni 2015, Bandung, Indonesia. (online). Tersedia http://portal.fi.itb.ac.id/snips2015/files/sn ips_2015_agus_budiyono_a67e404f84e5 98481cbb5716d3dcd735.pdf. Diakses 17 Februari 2016.

Demircioglu, T. \& Ucar, S. 2015. Investigating the Effect of Argument-Driven Inquiry in Laboratory Instruction. Educational Sciences: Theory \& Practice,2015, 15(1), 267-283. (Online). Tersedia : http://www.estp.com.tr. Diakses 23 Mei 2016.

Karisan, D \& Mustafa, S. 2016. "Contents Exploring the Preservice Science 
Quagga: Jurnal Pendidikan dan Biologi

Volume 9, Nomor 2, Juli 2017

Teachers' Written Argumentation Skills: the Global Climate Change Issue". International Journal of Environmental \& Science Education, 2016, 11(6), 13471363. (Online). Tersedia : https://www.google.com/search?q=Conte nts+Exploring+the+Preservice+Science+ Teachers\%E2\% 80\%99+Written+Argume ntation+Skills\%3A+the+Global+Climate +Change+Issue \&ie=utf-8\&oe=utf8 8dclient=firefox-b.. Diakses 18 Mei 2016.

Keraf, Gorys. 2010. Agumentasi dan Narasi. Jakarta: Gramedia Pustaka Utama.

Mutia, S.A.M. 2015. "Pembelajaran IPA Terpadu Pencemaran Lingkungan Dengan Argument-Driven Inquiry Untuk Meningkatkan Kemampuan Berargumentasi Ilmiah Dan Rasa Ingin Tahu Siswa SMP”. Tesis. Fakultas Keguruan dan Ilmu Pendidikan, Universitas Pendidikan Indonesia, Bandung. (Tidak dipublikasikan).

Puji.T.A. 2014. "Penerapan Model Pembelajaran Problem Based Learning (PBL) Berbasis Kerangka Konstruksional Marzano Terhadap Kualitas Argumentasi Siswa pada Konsep Animalia di Kelas X SMA Negeri 2 Kuningan". Skripsi. Fakultas Keguruan dan Ilmu Pendidikan, Universitas Kuningan, Kuningan. (Tidak dipublikasikan).

Roshayati, F. 2012. Model Pembelajaran Sains Dengan Argumentasi Sebagai Alternatif Implementasi Pendidikan Karakter. Prosiding Seminar Nasional Inovasi Pembelajaran FPMIPA IKIP PGRI Semarang. (Online). Tersedia : http://prosiding.upgrismg.ac.id/index.php /semnas_ino/SEM_INO2012/paper/view File/226/175. Diakses 17 Februari 2016.

Sampson, V., Grooms, J., \& Walker, J. P. 2009. Argument-Driven Inquiry a way to promote learning during laboratory activities: An exploratory study. Science Education, 95(2), 42-45.
p-ISSN 1907-3089, e-ISSN 2651-5869

https://journal.uniku.ac.id/index.php/quagga

Siswanto, Kaniawati, \& I. Suhandi, A. 2014. "Penerapan Model Pembelajaran Pembangkit Argumen Menggunakan Metode Saintifik Untuk Meningkatkan Kemampuan Kognitif Dan Keterampilan Berargumentasi Siswa".Jurnal Pendidikan Fisika Indonesia 10, (2) (2014) 104-116. (Online). Tersedia : http://journal.unnes.ac.id/nju/index.php/J PFI/article/view/3347/3318. Diakses 17 Februari 2016.

Sukma, W.G. 2014. "Penerapan Model Argument-Driven Inquiry Dalam Pembelajaran IPA Untuk Meningkatkan Kemampuan Argumentasi Ilmiah Siswa SMP”. Skripsi. Fakultas Keguruan dan Ilmu Pendidikan, Universitas Pendidikan Indonesia, Bandung. (Tidak dipublikasikan).

Susanti, Rahmi. 2013. Pengaruh Penerapan Pembelajaran Berbasis Masalah Pada Praktikum Fotosintesis dan Respirasiuntuk Meningkatkan Kemampuan Generik Sains Mahasiswa Pendidikan Biologi. FKIP Unsri. Seminar Kenaikan Jabatan Lektol pada Fakultas FKIP Unsri 05 Mei 2013. (Online). Tersedia http://eprints.unsri.ac.id/3247/1/Makalah Seminar_Kenaikan_Jabatan.pdf. Diakses 26 Januari 2016. 